Journal of Social Sciences (COES\&RJ-JSS)

ISSN (E): 2305-9249 ISSN (P): 2305-9494

Publisher: Centre of Excellence for Scientific \& Research Journalism, COES\&RJ LLC

Online Publication Date: $1^{\text {st }}$ October 2016

Online Issue: Volume 5, Number 4, October 2016

http://centreofexcellence.net/J/JSS/JSS\%20Mainpage.htm

\title{
Instructional leadership in character education organization at three middle schools in Surabaya, East Java, Indonesia
}

${ }^{1}$ Sumarli, ${ }^{2}$ Ahmad Sonhadji K.H, ${ }^{3}$ Utami Widiyati, \&Imron Arifin

${ }^{1}$ Candidate of Doctorate in Education in Management, State University o Malang,

Indonesia

2Professor in Education Management, Post Graduate Program, State University of Malang, Indonesia

3Professor in English Education, Post Graduate Program, State University of Malang, Indonesia

¿Senior Lecturer, Doctorate in Education Management, Post Grduate Program, State

University, Malang, Indonesia

\begin{abstract}
:
This research was aimed at describing the instructional leadership in characer education organization at three middle schools in Surabaya, East Java, Indonesia. This research employed qualitative approach with multisite study design. Data were collected by indepht interview, observation, and documentation. This research revealed that the instructional leadership in the character education organization based on the national education regulation covering academic aspect, students character development, and educators professionalism, which could enhance the students achievement, teachers' responsibilities, disciplines, worship devotion, noble value behavior, and virtue.
\end{abstract}

Keywords:

Instructional leadership, Character education, State middle schools.

\section{Citation:}

Sumarli; K.H., Ahmad Sonhadji; Widiyati, Utami; Arifin, Imron (2016); Instructional leadership in character education organization at three middle schools in Surabaya, East Java, Indonesia; Journal of Social Sciences (COES\&RJ-JSS), Vol.5, No.4, pp: 580-594. 


\section{Introduction}

National education functioned to develop and shape characters and civilization of dignified nation in order to educate the nation life. This is aimed at developing the students' potential in order to become godly, noble, healthy, knowledgebale, smart, creative, independent, democratic, and responsible. National education emphasizes on the character building in order to create smart, rightous, and resilient nation generation.

Character education is higly needed considering the recent phenomena that shows us the morrale degradation, crisis in ethic and self determination, as well as the occuring conflicts across our country. Character education is expected to be effective alternative to solve such problems. The current condition deemands chracter education transformed to children from the beginning wholistically and continously from the early children education, primary education, middle education, and higher education.

Character education at schools is a planned effort to facilitate learners to acknowledge, care, and internalize character values integratively in learning process, learners development activities, and school management activity (Kemendiknas, 2011stca). In middle schools character education is viewed as very important since in this instant children psychologically have a developmental level at the stage of concrete operational. They tend to use their rational logic to view all situation and move to maturity.

In the instructional management, principals are expected to become responsible and accountable instructional leaders to attain educational objectives. Principals need to possess ability in activate and to sought various resources to attain the educational objectives. This means that the school management is a strategic media that can be used by the principals to build learners characters through their policies. Such action highly supports the National education ministrial decree No. 23, 2015 concerning character building.

It has been acknowledge that the roles of principals as the instructional leaders to develop professionalism, enhance the students achievement and develop quality of learning have been very important. Principals determin the success and failure of education. Principals are highly charged to employ character education principles covering: (1) clarity of tasks and responsibility, (2) work distribution on the basis of the right man on the right place, (3) unity of direction and policy, (4) organized, (5) dicipline, (6) fair and balanced , (7) inisiative, (8) togetherness, (9) sinergis, and (10) sincere (Kemendiknas, 2010a, 2010b).

By referencing on these principles, principals are expected to easily practice instructional leadership. There are three strategies to be done by the principals for enhancing the effectiveness of instructional process, which are: (1) modeling; (2) monitoring; and (3) professional dialogue and discussion. Modelling means exemplary behavior to be exposed to teachers and students. Monitoring means monitoring the teacher performance in classroom when the learning process happens. Professional dialogue and discussion means actively, effectively, interactively, inspiratively, aspiratively, productively, democratically, and scientifically talk about outcomes of performance appraishal and follow up plan for improving the quality of learning process and outcomes. Referring to the principles of instructional leadership developed by the Instructional Leadership Redesign Comission in 2008 (Riyanto, 2010), the school principals can employ the following programs: (1) continuous improvement, (2) learning culture development, (3) 
learning outcomes appraishal, (4) teachers professional development, (5) school management organization, (6) ethics, and (7) differences awareness in character education organization. These emphasize that the instructional management and leadership are strategic ways to build characters at schools.

Based on the researcher premilinary study, there have been three schools implementing the character education. These are the state middle school 1, 6, and 22 Surabaya (SMP Negeri 1, SMP Negeri 6, and SMP Negeri 22 Surabaya). The main focus of this research were (1) instructional leadership planning in the character education organization, (2) implementation of the instructional leadership in character education organization, (3) instructional leadership evaluation in character education organization, and (4) alternatives of problem solvings in the implementation of instructional leadership in character education and (5) impact of the instructional leadership in character education organization.

\section{Research method}

This research employed the qualitative approach and multisite study design (Moleong, 2006), constant comparative technique of the three middle schools in Surabaya. They were State middle school 1, 6, and 22 Surabaya or the so called SMP Negeri di Surabaya, yaitu SMP Negeri 1 Surabaya, SMP Negeri 6 Surabaya, dan SMP Negeri 22 Surabaya. These research was designed using multisite approach due to having similarities in characteristics, which were (1) middle schools, (2) state schools, (3) located in Surabaya, and (4) under the authority of the Department of education in Surabaya. By this design, it is ecpected to result stable theories developement.

Data was collected by using indepth interview, participant observation, and documentation. The researcher played his role as the key instgrument. The presence of the researcher was acknowledge by the community of the three mentioned schools aiming at avoiding misunderstanding that can hinder the research. The data analysis was done in two stages, which was within single site analysis and cross site analysis. To ensure the validity of data, the researcher employ credibility, transferability, dependability, and confirmability.

\section{Research results}

This research revealed the following results.

\section{a. Instructional Leadership Planning in the Organization of Character Education}

The instructional leadership plannig in the orgniatization of character education were chategorized into the sources, reference pattern, management, main program, and socialization process as shown in table 1. 
Table 1 Instructional leadership plan in the organization of the three sites in the organization of character education

\begin{tabular}{|c|c|c|c|c|}
\hline Chategory & Site 1 & Site 2 & Site 3 & $\begin{array}{ll}\text { Cross } & \text { case } \\
\text { findings } & \\
\end{array}$ \\
\hline Sources & $\begin{array}{l}\text { Govermental } \\
\text { rules and } \\
\text { policies of } \\
\text { Education } \\
\text { department of } \\
\text { Surabaya } \\
\text { Municipality }\end{array}$ & $\begin{array}{l}\text { Global } \\
\text { situation, } \\
\text { Govermental } \\
\text { rules and } \\
\text { policies of } \\
\text { Education } \\
\text { department of } \\
\text { Surabaya } \\
\text { Municipality }\end{array}$ & $\begin{array}{l}\text { Governmental } \\
\text { regulation on } \\
\text { the } 8 \text { standards } \\
\text { and policies of } \\
\text { Education } \\
\text { department of } \\
\text { Surabaya } \\
\text { Municipality }\end{array}$ & $\begin{array}{l}\text { Govermental } \\
\text { rules and } \\
\text { policies of } \\
\text { Education } \\
\text { department of } \\
\text { Surabaya } \\
\text { Municipality }\end{array}$ \\
\hline $\begin{array}{l}\text { Referrence } \\
\text { patterns }\end{array}$ & Vision, mission & $\begin{array}{l}\text { Vision, } \\
\text { mission, } \\
\text { objectives }\end{array}$ & $\begin{array}{l}\text { Vision, } \\
\text { mission, } \\
\text { objectives }\end{array}$ & Vision, mission \\
\hline Managemenrt & $\begin{array}{l}\text { RKS, RKAS, } \\
\text { Organization } \\
\text { structures }\end{array}$ & $\begin{array}{l}\text { RKS, RKAS, } \\
\text { Organization } \\
\text { structures }\end{array}$ & $\begin{array}{l}\text { RKS, RKAS, } \\
\text { Organization } \\
\text { structures }\end{array}$ & $\begin{array}{l}\text { RKS, RKAS, } \\
\text { Organization } \\
\text { structures }\end{array}$ \\
\hline Main program & $\begin{array}{l}\text { Academic } \\
\text { activities, } \\
\text { curriculair, and } \\
\text { extracurriculair } \\
\text { Habituation } \\
\text { activities } \\
\text { Educators } \\
\text { and educatonal } \\
\text { staffs } \\
\text { professionalis } \\
\text { m }\end{array}$ & $\begin{array}{l}\text { 1. Academic } \\
\text { activities, } \\
\text { curriculair, and } \\
\text { extracurriculair } \\
\text { 2. Habituation } \\
\text { activities } \\
\text { 3. Educators } \\
\text { and educatonal } \\
\text { staffs } \\
\text { professionalism }\end{array}$ & $\begin{array}{l}\text { 1. Academic } \\
\text { activities, } \\
\text { curriculair, and } \\
\text { extracurriculair } \\
2 . \\
\text { Culturalization } \\
\text { and habituation } \\
\text { activities }\end{array}$ & $\begin{array}{l}\text { Academic } \\
\text { activities, } \\
\text { curriculair, and } \\
\text { extracurriculair } \\
\text { Culturalization } \\
\text { activities }\end{array}$ \\
\hline Socialization & $\begin{array}{l}\text { School } \\
\text { community } \\
\text { members and } \\
\text { parents }\end{array}$ & $\begin{array}{l}\text { School } \\
\text { community } \\
\text { members and } \\
\text { parents }\end{array}$ & $\begin{array}{l}\text { School } \\
\text { community } \\
\text { members and } \\
\text { those who care } \\
\text { for education }\end{array}$ & $\begin{array}{l}\text { School } \\
\text { community } \\
\text { members }\end{array}$ \\
\hline
\end{tabular}

The governmental regulations and local government policies influenced much on the instructional leadership plan in organizing the character education. The instructional leadership implementation has been formulated by having the vision, mission, and school program. The forms of such planning was emerged in the school work plan or the socalled rencana kerja sekolah (RKS) and the school budget and activities plan or the socalled (RKAS), as well as the organization structure. To enhance the comprehension of the instructional leadership plan, socialization to all the school community members was done efectively. 


\section{b. Implementation of the Instructional Leadership in the Character Education Organiation}

The instructional leadership implementation could be briefly explained on the basis of the guidance category, academic activities, culturaliation of characters, those who involve, and the principals roles. The comparition on this matter among the three sites were as stated in Table 2

Table 2 Instructional leadersihip in education character implmentation in the three sites

\begin{tabular}{|c|c|c|c|c|}
\hline Category & Site 1 & Site 2 & Site 3 & Cross Sites \\
\hline Guideline & $\begin{array}{l}\text { RKS, } \\
\text { Ministrial } \\
\text { decree No } \\
23 / 2015 \\
\end{array}$ & $\begin{array}{l}\text { RKS, } \\
\text { Ministrial } \\
\text { Decree No } \\
23 / 2015\end{array}$ & $\begin{array}{l}\text { RKS, Ministrial } \\
\text { Decree } \\
\text { No23/2015 and } \\
\text { SOP }\end{array}$ & $\begin{array}{l}\text { RKS and } \\
\text { ministrial } \\
\text { decree No } \\
23 / 2015\end{array}$ \\
\hline Objectives & $\begin{array}{l}\text { Attainment of } \\
\text { the character } \\
\text { building and } \\
\text { noble morale } \\
\text { for the students } \\
\text { wholistically, } \\
\text { integredly, and } \\
\text { balanced as } \\
\text { mandated by } \\
\text { the graduate } \\
\text { competence } \\
\text { standards. }\end{array}$ & $\begin{array}{l}\text { High quality } \\
\text { godly, etical, } \\
\text { skillful, } \\
\text { environmentally } \\
\text { and globally } \\
\text { aware students. }\end{array}$ & $\begin{array}{l}\text { High achievers, } \\
\text { nobler, godly, } \\
\text { and } \\
\text { environmentally } \\
\text { aware students }\end{array}$ & $\begin{array}{l}\text { High achievers, } \\
\text { character based, } \\
\text { and } \\
\text { environmentally } \\
\text { aware students. }\end{array}$ \\
\hline $\begin{array}{l}\text { Academic } \\
\text { Activities }\end{array}$ & $\begin{array}{l}\text { Implementing } \\
\text { the } 2013 \\
\text { curriculum and } \\
\text { promoting the } \\
\text { smart student } \\
\text { program } \\
\text { Having the } \\
\text { curriculum } \\
\text { developement } \\
\text { out o the } \\
\text { working times } \\
\text { Doing } \\
\text { activities to } \\
\text { enhance the } \\
\text { middle school } \\
\text { students } \\
\text { national } \\
\text { examination } \\
\text { achievement. } \\
\text { Self } \\
\text { development } \\
\text { activities } \\
\text { Religious } \\
\text { coaching in the }\end{array}$ & $\begin{array}{l}\text {.Curriculum } 2013 \\
\text { curriculair } \\
\text { activities } \\
\text {.Extra cuirriculair } \\
\text {.Developmental } \\
\text { activities } \\
\text { invloving the } \\
\text { counselling } \\
\text { practices. }\end{array}$ & $\begin{array}{l}\text { 1. Focusing on } \\
\text { the academic } \\
\text { achievement } \\
\text { using the } 2013 \\
\text { curriculum } \\
\text { 2. Allocating } \\
\text { educational } \\
\text { resources to } \\
\text { achieve vision, } \\
\text { mission, and } \\
\text { objectives } \\
\text { 3. Operating } \\
\text { effective school } \\
\text { 7. Implementing } \\
\text { teachers and } \\
\text { staffs } \\
\text { development }\end{array}$ & $\begin{array}{l}\text { Curriculair and } \\
\text { extracurriculair } \\
\text { activities on the } \\
\text { basis of the } 201 \\
\text { curriculum }\end{array}$ \\
\hline
\end{tabular}




\begin{tabular}{|c|c|c|c|c|}
\hline & $\begin{array}{l}\text { effective hours. } \\
\text { Doing } \\
\text { extracuriculair } \\
\text { effectively. }\end{array}$ & & & \\
\hline $\begin{array}{l}\text { Character } \\
\text { Culturalization }\end{array}$ & $\begin{array}{l}\text { Cultivating } \\
\text { spiritual and } \\
\text { morale values } \\
\text { Cultivating } \\
\text { nation and } \\
\text { unity in } \\
\text { diversity } \\
\text { values } \\
\text { Cultivating } \\
\text { positive } \\
\text { uinteractionam } \\
\text { ong students } \\
\text { and teachers } \\
\text { Developing } \\
\text { students } \\
\text { positive } \\
\text { interation, } \\
\text { Self maintenance } \\
\text { and school } \\
\text { environmental } \\
\text { maintenance, } \\
\text { Developing } \\
\text { students } \\
\text { potential } \\
\text { wholistically, } \\
\text { Parents } \\
\text { involvement at } \\
\text { school }\end{array}$ & $\begin{array}{l}\text {.Implementimg } 5 \\
\text { S daily } \\
\text {.Implementing } \\
\text { cukture: Prsyig } \\
\text { together, } \\
\text { reciting holy } \\
\text { books, } \\
\text { singgingnationa } \\
\text { l anthem, } \\
\text { literacy, singing } \\
\text { traditional } \\
\text { songs, flag } \\
\text { raining, } \\
\text { morning } \\
\text { rehearsal } \\
\text {.Habituation of } \\
\text { the healthy and } \\
\text { charming friday } \\
\text {.Breakfast } \\
\text { together } \\
\text {.Honesty } \\
\text { i.Parents care }\end{array}$ & $\begin{array}{l}\text {.Culturalization } \\
\text { of } 6 \mathrm{~S} \\
\text {..Culturalization } \\
\text { of literacy, } \\
\text { i.Doing Duha } \\
\text { prayer, } \\
\text { t.Doing clean } \\
\text { friday } \\
\text { i.Doing Ants } \\
\text { Power (Gertak } \\
\text { Semut) } \\
\text { i.Reciting Juz } \\
\text { Ama and } \\
\text { '.Dhuhur prayer } \\
\text { together }\end{array}$ & $\begin{array}{l}\text { Development of } \\
\text { religion } \\
\text { education, local } \\
\text { culture, } \\
\text { nasionalism, } \\
\text { environmental } \\
\text { aareness and } \\
\text { health care }\end{array}$ \\
\hline $\begin{array}{l}\text { Involved } \\
\text { Parties }\end{array}$ & $\begin{array}{l}\text { Teachers and } \\
\text { Parents }\end{array}$ & $\begin{array}{l}\text { School } \\
\text { community and } \\
\text { Parents }\end{array}$ & $\begin{array}{l}\text { School } \\
\text { community and } \\
\text { community }\end{array}$ & $\begin{array}{l}\text { School } \\
\text { comunity and } \\
\text { parents }\end{array}$ \\
\hline Principals & $\begin{array}{l}\text { Multifunction } \\
\text { role model } \\
\text { (EMASLIM) }\end{array}$ & $\begin{array}{l}\text { Role model and } \\
\text { motivator }\end{array}$ & $\begin{array}{l}\text { Role model and } \\
\text { motivator }\end{array}$ & $\begin{array}{l}\text { Role model and } \\
\text { motivator }\end{array}$ \\
\hline
\end{tabular}

The implementation of instuctional leadership in the organization of education character have run well by basing on the ministrial decree No 23/2015 and RKS (School Work Plan). The instructional leadership impacted the graduates having high achievement, good characters, and environmentally caring. Academically, the instructional leadership was related to the 2013 curriculum and extracukair activities. In terms of the culturalization, the instructional leadership concerned the development of religion education, local cultures, nationalism, environmentally caring, and health care. The imlementation of the instructional leadersip in the organization of character education involved all school community and parents. Principals influenced the instructional leadership in the organization of character education as role model and motivator. 
c. Evaluaion of the instructional leadership and the organization of character education

The evaluation of the instructional leadership in the organization of character education in three sites was analized using four categories, which ere evakuation standard reference, evaluated aspects, evaluation proceedures, and evaluation outcomes. Based on these four categories, the evaluation could be described in the following table.

Table 3 Evaluation of Instructional leadership in the organization of character education in the three sites

\begin{tabular}{|c|c|c|c|c|}
\hline Category & Site 1 & Site2 & Site 3 & Cross sites \\
\hline $\begin{array}{l}\text { Standard } \\
\text { Reference }\end{array}$ & $\begin{array}{l}\text { La w no } \\
\text { 20/2003 } \\
\quad \text { Goverment } \\
\text { al rgulation No } \\
\text { 32/2013 } \\
\quad \text { Education } \\
\text { Ministrial } \\
\text { Decree No } \\
\text { 19/2007 } \\
\quad \text { Education } \\
\text { Ministrial } \\
\text { Decree No 54, } \\
\text { 64, 65, 66, } \\
\text { 81A/2013 } \\
\quad \text { Education } \\
\text { Ministrial } \\
\text { Decree No } \\
\text { 23/2015 }\end{array}$ & $\begin{array}{l}\text { Law no } \\
\text { 20/2003, } \\
\quad \text { Ministrial } \\
\text { Decree No 22, 23, } \\
\text { 41/2007, } \\
\quad \text { Education } \\
\text { Ministrial Decree } \\
\text { No 13, 16, 19, 20, } \\
\text { 23, 41/2007, } \\
\text { Education } \\
\text { Ministrial Decree } \\
\text { No 64, 65, 66, } \\
\text { 81A/2013 } \\
\text { Education } \\
\text { Ministrial Decree } \\
\text { No 23/2015 }\end{array}$ & $\begin{array}{l}\text { Law no } \\
\text { 20/2003, } \\
\text { Ministrial } \\
\text { Decree No 22, } \\
\text { 23, 41/2007, } \\
\text { Ministrial } \\
\text { Decree No 13, } \\
\text { 16, 19, 20, 23, } \\
\text { 41/2007, } \\
\text { Ministrial } \\
\text { Decree No 64, } \\
\text { 65, 66, } \\
81 \mathrm{~A} / 2013 \\
\text { Education } \\
\text { Ministrial } \\
\text { Decree No } \\
\text { 23/2015 }\end{array}$ & $\begin{array}{l}\text { Law no } \\
\text { 20/2003, } \\
\text { Education } \\
\text { Ministrial } \\
\text { Decree No } \\
22,23, \\
41 / 2007, \\
\text { Education } \\
\text { Ministrial } \\
\text { Decree No } \\
\text { 13, 16, 19, 20, } \\
23,41 / 2007, \\
\text { Education } \\
\text { Ministrial } \\
\text { Decree No } \\
\text { 64, 65, 66, } \\
81 \mathrm{~A} / 2013 \\
\text { Education } \\
\text { Ministrial } \\
\text { Decree No } \\
\text { 23/2015 }\end{array}$ \\
\hline Asp & $\begin{array}{l}\text { Students } \\
\text { Academics } \\
\text { Students } \\
\text { Characters } \\
\text { Educational } \\
\text { Resource } \\
\text { Proessionalism }\end{array}$ & $\begin{array}{l}\text { Students } \\
\text { Academics } \\
\text { Students Charaters } \\
\text { Educational } \\
\text { Resource } \\
\text { Performance }\end{array}$ & $\begin{array}{l}\text {.. Students } \\
\text { Academics } \\
\text {.. Students } \\
\text { Caracters } \\
\text { i. Educational } \\
\text { Resource } \\
\text { Professionalis } \\
\text { m } \\
\end{array}$ & $\begin{array}{l}\text { Students } \\
\text { Academics } \\
\text { Students } \\
\text { Characters } \\
\text { Educational } \\
\text { Resource } \\
\text { Professionalis } \\
\mathrm{m}\end{array}$ \\
\hline Proceedures & $\begin{array}{l}\text { UH (Daily } \\
\text { Assessment), } \\
\text { UTS 1\&2 (Mid- } \\
\text { term } \\
\text { assessment), } \\
\text { UK } \\
\text { (Competence } \\
\text { evaluation), US } \\
\text { (School } \\
\text { Evaluation), }\end{array}$ & $\begin{array}{l}\text { Otentic evaluation, } \\
\text { Self Evaluation, } \\
\text { port folio, UH } \\
\text { (Daily } \\
\text { Assessment), UTS } \\
\text { (Mid-term } \\
\text { assessment), UK } \\
\text { (Competence } \\
\text { Evaluation), US } \\
\text { (School }\end{array}$ & $\begin{array}{l}\text { UH (Daily } \\
\text { Assessment), } \\
\text { UTS(Mid-term } \\
\text { assessment), } \\
\text { US (School } \\
\text { Evaluation), } \\
\text { UN (National } \\
\text { Evaluation), } \\
\text { UK } \\
\text { (Competence }\end{array}$ & $\begin{array}{l}\text { UH (Daily } \\
\text { Assessment), } \\
\text { UTS(Mid- } \\
\text { term } \\
\text { assessment), } \\
\text { US (School } \\
\text { Evaluation), } \\
\text { UN (National } \\
\text { Evaluation), } \\
\text { UK }\end{array}$ \\
\hline
\end{tabular}




\begin{tabular}{|c|c|c|c|c|}
\hline & $\begin{array}{l}\text { UN (National } \\
\text { Evaluation) } \\
\text { Attitude and } \\
\text { Behavior } \\
\text { Supervision, } \\
\text { SKP (Employee } \\
\text { Work Target), } \\
\text { PKB } \\
\text { (Continuous } \\
\text { competence } \\
\text { development) }\end{array}$ & $\begin{array}{l}\text { Evaluation), UN } \\
\text { (National } \\
\text { Evaluation) } \\
\text { Attitude and } \\
\text { behavior } \\
\text { Supervision, EDG } \\
\text { (Teachers Self } \\
\text { Evaluation), PKG } \\
\text { (Teachers } \\
\text { Performance } \\
\text { Apraishal), SKP } \\
\text { (Employee Work } \\
\text { Target), PKB } \\
\text { (Continuous } \\
\text { competence } \\
\text { development) } \\
\end{array}$ & $\begin{array}{l}\text { Evaluation) } \\
\therefore \text { Attitude and } \\
\text { behavior } \\
\text {. Supervision, } \\
\text { PKG (Teachers } \\
\text { Performance } \\
\text { Apraishal), } \\
\text { SKP } \\
\text { (Employee } \\
\text { Work Target), } \\
\text { PKB } \\
\text { (Continuous } \\
\text { competence } \\
\text { development) }\end{array}$ & $\begin{array}{l}\text { (Competence } \\
\text { Evaluation) } \\
\text { Attitude and } \\
\text { behavior } \\
\text { Supervision, } \\
\text { PKG } \\
\text { (Teachers } \\
\text { Performance } \\
\text { Apraishal), } \\
\text { SKP } \\
\text { (Employee } \\
\text { Work Target), } \\
\text { PKB } \\
\text { (Continuous } \\
\text { competence } \\
\text { development) }\end{array}$ \\
\hline Outcomes & $\begin{array}{l}\text { Students } \\
\text { achievement } \\
\text { The increase of } \\
\text { students } \\
\text { awareness } \\
\text { towards others } \\
\text { and } \\
\text { environment } \\
\text { The increase of } \\
\text { teachers } \\
\text { responsibility }\end{array}$ & $\begin{array}{l}\text { Students } \\
\text { achievement } \\
\text { The increase of } \\
\text { students awareness } \\
\text { towards others and } \\
\text { environment } \\
\text { The increase of } \\
\text { awareness among } \\
\text { teachers and } \\
\text { students }\end{array}$ & $\begin{array}{l}\text { Students } \\
\text { achievement } \\
\text {.. The increase of } \\
\text { students } \\
\text { awareness } \\
\text { towards others } \\
\text { and } \\
\text { environment } \\
\text {. The increase of } \\
\text { teachers } \\
\text { responsibility }\end{array}$ & $\begin{array}{l}\text { Students } \\
\text { achievement } \\
\text { The increase } \\
\text { of students } \\
\text { awareness } \\
\text { towards } \\
\text { others and } \\
\text { environment } \\
\text { The increase } \\
\text { of teachers } \\
\text { responsibility }\end{array}$ \\
\hline
\end{tabular}

The governmental regulation, mainly law no 20/2003, Educationn ministry decree no 22, $23,41 / 2007$, Education ministry decree no 13, 16, 19, 20, 23, 41/2007, Education ministry decree no $64,65,66,81 \mathrm{~A} / 2013$ and Education ministry decree no 23/2015 determined evaluation of instructional leadership in rthe organization of education character covering students academics, students characters, and education resources professionalism. The Evaluation proceedures of the instructional leadership in the organization of character education concerned with UH (Daily assessment), UTS Mid-terms assessment), UK (Competence Evaluation), US (School Evaluation), UN (National Evaluation), Daily attitude and behavior, supervision, UKG (Teachers Conpetence Evaluation), SKP (Employee Work Target), PKB (Continuous professional development). The higher the students acievement, the better the students awareness towards others and environement, the better the teachers responsibilities which impacted the instructional leadership in the organiation of character education.

d. Problems and Problem solving alternative in the instructional leadership for the organization of character education

These can be expalined through the following table.

Table 4 Findings of Problema and Problem solcing alternative in the instructional leadership for the organization of character education

\begin{tabular}{lllll}
\hline Category & Site 1 & Site 2 & Site 3 & Cross Sites \\
\hline
\end{tabular}


Instructional leadership in character education organization....

\begin{tabular}{|c|c|c|c|c|}
\hline $\begin{array}{l}\text { Implemetation } \\
\text { Model }\end{array}$ & $\begin{array}{l}\text { Integration of } \\
\text { study matters } \\
\text { and character } \\
\text { education }\end{array}$ & $\begin{array}{l}\text { Integrated and } \\
\text { Separated }\end{array}$ & $\begin{array}{l}\text { Integrated and } \\
\text { Separated }\end{array}$ & $\begin{array}{l}\text { There were two } \\
\text { models of } \\
\text { character } \\
\text { education,: (1) } \\
\text { integrated in the } \\
\text { subject matters, } \\
\text { and (2) separated }\end{array}$ \\
\hline Problem & $\begin{array}{l}\text {. No budget } \\
\text {.Lack of healty } \\
\text { living and } \\
\text { clean } \\
\text { awareness } \\
\text {.Low } \\
\text { commitment of } \\
\text { the school } \\
\text { cmmunity } \\
\text {. No program } \\
\text { pregress } \\
\text { measurement } \\
\text {.No regulation } \\
\text { and evaluation }\end{array}$ & $\begin{array}{l}\text { L.Leadership } \\
\text { model } \\
\text { 2.Lack of the } \\
\text { community } \\
\text { commitment } \\
\text { 3.Professional } \\
\text { development } \\
\text { 1.Regulation and } \\
\text { Evaluation }\end{array}$ & $\begin{array}{l}\text {.Not a priority } \\
\text { yet } \\
\text { Regulation and } \\
\text { Evaluation } \\
\text {.Differences in } \\
\text { attitude and } \\
\text { behavior }\end{array}$ & $\begin{array}{l}\text {. No fund or } \\
\text { budget } \\
\text {.Lack of healty } \\
\text { and clean living } \\
\text { awareness } \\
\text {.Low commitment } \\
\text { of the school } \\
\text { community } \\
\text {. No progress } \\
\text { measurement } \\
\text {.No regulation and } \\
\text { evaluation }\end{array}$ \\
\hline $\begin{array}{l}\text { Problem } \\
\text { solving }\end{array}$ & $\begin{array}{l}\text {.Improvement } \\
\text { of RKAS } \\
\text { '.CSR } \\
\text { i.Improvement } \\
\text { of integration } \\
\text { concept } \\
\text {.Principals as } \\
\text { role models } \\
\text { i.Maintaining } \\
\text { good tradition } \\
\text { i.Being the } \\
\text { consideration } \\
\text { of graduation }\end{array}$ & $\begin{array}{l}\text {.Enhancement of } \\
\text { community } \\
\text { commitment } \\
\text { i.Cooperation } \\
\text { with all parties } \\
\text { i.Forming } \\
\text { community } \\
\text { t.Empowerment } \\
\text { of EDG, } \\
\text { MGMP } \\
\text { i.Principals as } \\
\text { role model } \\
\text { i.Becoming the } \\
\text { consideration } \\
\text { for graduation } \\
\text { and level } \\
\text { promotion }\end{array}$ & $\begin{array}{l}\text {.Becoming } \\
\text { school program } \\
\text { Referencing to } \\
\text { the Education } \\
\text { ministrial } \\
\text { decree No } \\
23 / 2015 \\
\text { Principals as } \\
\text { role models } \\
\text {.Respecting } \\
\text { differences } \\
\text {.Interpersonal } \\
\text { and familiar } \\
\text { communication }\end{array}$ & $\begin{array}{l}\text { mprovement of } \\
\text { RKAS } \\
\text { 'SR } \\
\text { mprovement of } \\
\text { integration } \\
\text { concept } \\
\text { 'rincipals as role } \\
\text { models } \\
\text { Taintaining good } \\
\text { tradition } \\
\text { ieing the } \\
\text { consideration of } \\
\text { graduation and } \\
\text { level promotion }\end{array}$ \\
\hline
\end{tabular}

There were differences in models of instructional management and character education among the three sites, which were, integrating the character education with the subject matters and separated model. Both mideks infkuence the instructional leadership practices. The outstanding problem laid on the uncertainty of the fund, lack of the clean and healthy living, low commitment of the school community members, having no progress and outcome measurement, having no regulation and follow up of the outcomes. Such problems could be managed if there as an improvement of RKAS (School Budget Work Plan), a usage of CSR, an improvement of the integration between character and subject matters, the enhancement of school community members commitment, a condition of being the principals as models, a condition of having differfences respect among the 
school community members, and the condition that results of the character education as considered for level promotion and graduation.

\section{e. Impacts of the Instructional Leadership in Education Character Organization}

Impacts of the Instructional Leadership in Education Character Organization can be explained in table 5 ..

Table 3.5 Findings on the impacts of the Instructional Leadership in the organization of Character Education in the three sites.

\begin{tabular}{|c|c|c|c|c|}
\hline Aspects & Site 1 & Site 2 & Site 3 & Cross Sites \\
\hline Principals & $\begin{array}{l}\text { Ecemplary } \\
\text { Feagure } \\
\text { Democratic and } \\
\text { Acceptance in } \\
\text { diversity }\end{array}$ & $\begin{array}{l}\text { Role Model } \\
\text { Democratic and } \\
\text { acceptance in } \\
\text { diversity }\end{array}$ & $\begin{array}{l}\text { 1.Democratic and } \\
\text { Acceptance in } \\
\text { Diversity } \\
\text { 2.Focus on the } \\
\text { school program } \\
\text { 3.Having support } \\
\text { from } \\
\text { subordinates }\end{array}$ & $\begin{array}{l}\text {.Role Model and } \\
\text { Exemplary } \\
\text { feagure } \\
\text {.Democratic and } \\
\text { acceptance in } \\
\text { diversity }\end{array}$ \\
\hline Teachers & $\begin{array}{l}\text { Discipline } \\
\text { Professional } \\
\text { Responsible }\end{array}$ & $\begin{array}{l}\text { Professional } \\
\text { Responsible } \\
\text { Having an increase } \\
\text { of awareness on th } \\
\text { importance of } \\
\text { Character } \\
\text { Education } \\
\text { High sense of family }\end{array}$ & $\begin{array}{l}\text { l.Awareness of the } \\
\text { enhancement of } \\
\text { social and } \\
\text { personal } \\
\text { competences } \\
\text { 2.Responsible } \\
\text { 3.Respecting others } \\
\text { t.Becoming } \\
\text { exemplary to } \\
\text { students }\end{array}$ & $\begin{array}{l}\text {.Awareness of the } \\
\text { enhancemenet of } \\
\text { social and } \\
\text { personal } \\
\text { competences } \\
\text {.Responsible } \\
\text {.Professonal }\end{array}$ \\
\hline Students & $\begin{array}{l}\text { Behavior } 3 \mathrm{~S} \\
\text { Good prayer } \\
\text { Discipline } \\
\text { High Solidarity } \\
\text { Clean living }\end{array}$ & $\begin{array}{l}\text { Spirit and learning } \\
\text { achievement were } \\
\text { enhanced } \\
\text { Behavior } 5 \mathrm{~S} \\
\text { High solidarity } \\
\text { Clean Living } \\
\text { Good Deed } \\
\text { Complying schools } \\
\text { regulation } \\
\text { (discipline) }\end{array}$ & $\begin{array}{l}\text {..Noble Attitude } \\
\text { and behavior } \\
\text { 2.Responsible } \\
\text { 3.Diligent in } \\
\text { learning } \\
\text { f.Positive thinking } \\
\text { j.Good Deed } \\
\text { j.Being good in the } \\
\text { community }\end{array}$ & $\begin{array}{l}\text {.Noble attitude } \\
\text { and behavior } \\
\text {.Responsible } \\
\text {.Dilligent in } \\
\text { learning } \\
\text {.Good Deed }\end{array}$ \\
\hline
\end{tabular}

From this table, it can be described that the impact on the instructional leadership of the character education organization concerned the roles of the principals in being role models, democratic, aspirative, and acceptance in diversity. As for the impact for teachers concerned the awareness in enhan cing the personal and social competences, being responsible, and working professionally. The impacts towards students concerned the noble attitude and behavior, being responsible, dilligent in learning, and having good deeds. 


\section{f. The Instructional Leadership in the character education in three sites.}

The instructional leadership in nthe character education organiation is described wholistically, beginning from the planning, which was formulated on the basis of governmental and provincial regulation and policies, designed in vision and mission as refefrences of the School Work and School Budget Work Plans or the so-called RKSRKAS through the implementation and evaluation of the instructional leadership. The RKS-RKAS covered the academic or curriculair and extracurriculair programs and the culturalization as wellas socialization of the characters within the school community members. Therefore, the implementation of the instructional leadership in the organiation of the character education was based on the School Work Plan or the so-called RKS comprising the academic aspects and culturalization aspect of the characters being educated and was involving all school community members as well as parents and students. Meanwhile, the principals were becoming the role models and motivators. Evaluation of the instuctional leadership in the organization of the Character education was based on the governmental regulation that governed the evaluation of academic aspects, students characters, and Educators through examination and other evaluation that resulted the enhancement of students' achievement and students awareness, and the enhancement of the teachers' responsibilities. To overcome the problem of the inexistance of funding, having low awareness in healthy and clean living, having no measurements of progress and outcomes, having no regulation and follw up, the alternative solution turned out to be the improvement of RKAS, using CSR, improvement of the integration concepts of character education and subject matters, the maintenance of good tradition, the enhancement of the school cimmunity members awareness, the existance of principals as role models, the respect of diversity, and the consideration of the character education results for class level promotion and graduation. The impacts of the instructional leadership in the organiation of character education were obvious on the [principals' attitude and behaviors, teachers, and students for being responsible, discipline, obeydiance in good deeds, and having noble values.

Of the overall findings in the three sitesm, it can be shown in the final findings as the orientation of the instrutional leadership in the organization of character education as follow:

Instructional Leadership.....

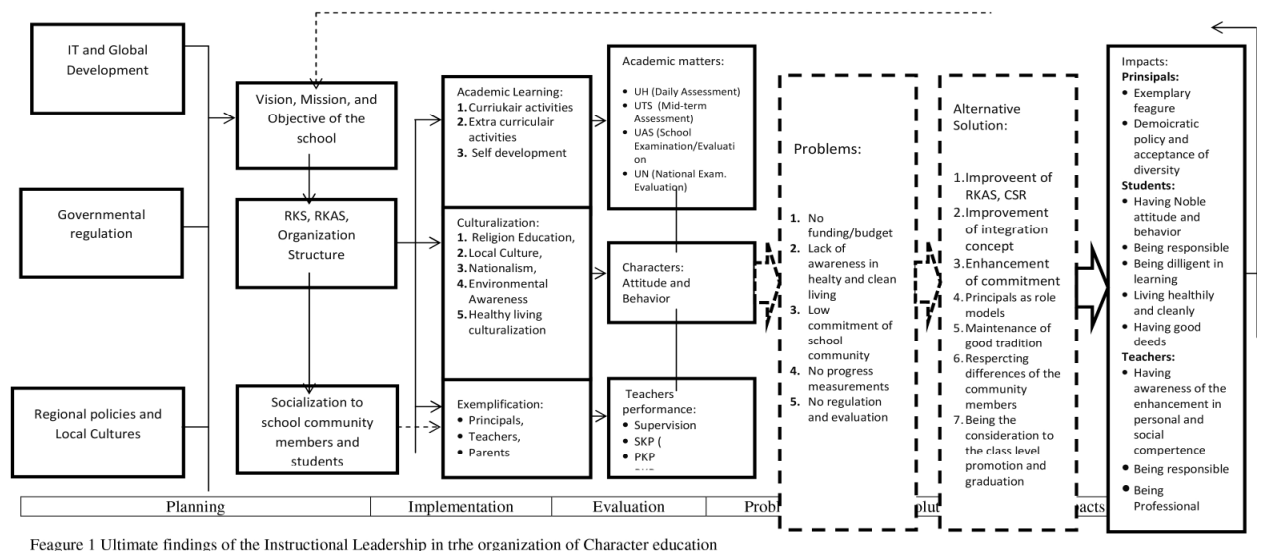




\section{Discussion}

a. Planning of the instructional leadership in the organiation of the character education

The instructional leadership plannig was designed on the basis of national law, governmental regulation, and regional govvernment policies in terms of the vission and mission as the reference of the school polaning the so-called RKS-RKAS which technically covered curriculair and extracurricuriculair activities, culturalization activities socialized to all schools community members. Consequently, those state schools under the authority of the Surabaya municipal government had to follow the national government regulation and minicipal policies. Such regulation was dealt with the law No. 20, 2003 of the National Education System, Education ministrial No. 22, 2006 of the content standard of the curriculum, education ministrial decree No. 23, 2006 of the graduate competence standard, education ministrial decree No. 41, 2007 of the process standard, education ministrial decree No. 16 tahun 2007 of teacher standard, Education ministrial decree No. 13, 2007 of the Principal standard, Education ministrial decree No. 22 tahun 2007 of the education facilities and infrastructures, Education ministrial decree No. 19, 2007 of the management standard, and Education ministrial decree No. 20, 2007 of the evaluation standard, Education ministrial decree No. 54, 64, 65, 66, and 81A, 2013. Related to the character education, the implementation was based on the Education ministrial decree No.23, 2015 of the character building the so-called Penumbuhan Budi Pekerti. In chapter 2 of the Education ministrial decree No. 23, 2015, it has been stated that the character building at schools make the school a friend of students learning which should be enjoyable, and friend of teachers, and educational staffs.

The plan was made in the school work plan and school work budget plan or the so-called RKS and RKAS. These plan were actualized on the basis of the school organization structure. These plans were designed on the basis of national and local educational objectives which enabled students to highly achieve their academic and non acadcemic performances and which enabled students to have god characters and to have environmental awareness. Thus, the ultimate school program was aimed at curriculum and values culturalization. Such situation is consistant with the notion of instructional leadership by Instructional Leadership Redesign Commission tahun 2008 quoted by Kemendiknas (2011a) which says that instructional leadership among others is related with the enhancement of quality of learning continuously. The instructional leadership pays attention on teaching and learningmimpacting to the students learning through teachers. Therefore, the instructional leadership focuses on the enhancement of learning quality with teachers' professionalis.

\section{b. Implementation of the instructional leadership in the organiation of character education}

The instructional leadership implementation was based on the school work plan or the socalled RKS covering academic and non academic aspects as well as culturalization of characters involving the overall school community members including principals, teachers, staffs, students, and parents. Such findings are in line with the Kemendiknas (2011a) stating that a way of mplementing the instructional leadership is implementing it at school. Kemendiknas (2010b) states that the development of characters at schools can be done by integrated process through (1) integrated learning process, (2) integrated school management, and (3) students activities. This means that the character education 
process needs developmental pattern whlistically and coordinated in each aspec of the school activitity.

Principals shall enrole as advisor to ensure the development of all potential at schools and to work with other educational managers in the concerns human resource management. The education management to create conducive learning environment and continuous improvement is the commitment of overall school managers. The ability of principal in these findings support Petterson (in Kemendiknas, 2010a) concerning the effective instructional leadership.

\section{c. Evaluation of the Instructional Leadership in the organiation of Character education}

The evaluation was based on the governmental regulation of education which inckuded academic aspects, students character, and educators professionalism through examination and other evaluations resulting the enhancement of students' achievement, students' awareness, and teachers' responsibilities. The three sites implemented the 2013 curriculum which was designed on the basis of the nation character and culture, civilization, and competence. The success of learning deals with the the mastery learning in the learning process. Learning mastery means having the attainment of competences covering knowledge, skills, attitudes, or values actalized in the habit of mind and action.

The professional development of the teachers covers overall efforts made by the principals to construct mental attitude of the teachers to be better educators in helping students achieve their goals. The reference of the evaluation concerned the law No. 20, 2003 of the national education system, governmental decree No. 32, 2013 of the National Education Standard, and the Education ministerial decree No. 19 tahun 2007, No. 54, 64, 65, 66, and 81A, 2013.

d. Problems and alternative solution of the problem in the implementaton of instructional leadership for the organiation of the character education.

Character education emphasizes on the best process, rather than the the best input. Schools are expected to be inclusive institution being rady in all forms of diversity of students, educators, and educational staffs, employees, and all other community members of the schools. The diversity power can be used to enhance the success of education through learning and character development. To solve problems faced in the implementation of the instructional leadership in terms of the lack of funding, lack of awareness in healthy and clean living, low level of the school community awareness, the inexistance of the progress and results measurements, as well as the inexistance of regulation, the principals can use alternative solution be improving the school work plan or RKAS, using CSR, improving the concept of integration ofcharacter education and subject matters, enhancing the school community members commitment, making the principals as role models, maintening good tradition of the schools, aand considering the character education results as the consideration of the class level promotion and graduation.

The principals turned out to involve and obtain resources available in the community to achieve vission, mission, and school as well as stake holder objectives. All of these resources were collected through donation of parents, school committee, company CSR, and alumni empowerment. The principals were also oblighted to sinergize with students 
and communities surrounding the schools. Such action is called wholistic approach. The success of the character education is, in turn, determined by the sinergy of the school internal component, students family, and external communities.

\section{e. Impacts of the Instructional leadership in the organization of Character education}

It was found out that the impacts of the instructional leadership in the organization of character education concerned the attitude and behavior of principals, teachers, and students of being more responsible, discipline, obediance in good deeds, and being godly and noble. Such instructonal leadership mostly deals with: (a) doing responsibilities professionally and respecting integrity and fairness, (b) becoming example and professionally giving support to implement code of ethic and norms, (c) making decisions in the context of respecting self and others, (d) coachin school community members in the event of changes of policy, social condition, political condition in order to enhance the students learning outcomes, (e) making decision to support the quality development which is suitable with the school vision and mission as well as school objectives, (f) considering jurispridence aspects, moral aspects, and ethical aspecs in making decision, and $(\mathrm{g})$ complying the rules and regulations.

\section{Conclusion and suggestion}

Generaly the instuctional leadership in the organization of the character education at schools results graduates who are high achiever, have god character, and are aware of the environement through planning process, implementation, and evaluation. The planning process of the instructional leadership for the character educastion concerned desgining plan on the basis of governmental rules and regulation as well as policies emerged in the school vision and mission as the reference to create school work plan the so-called RKSRKAS which tehnically covered intra and extra curriculair activities and the culturalization of the characters at schools which were also socialized to all schools committee members. The implementation of the instructional leadership for the organization of the character education was based on the school work plan the so-called RKS covering the academic aspects, culturalization activities involving principals, rteachers, educational staffs, students, parents, and extrernal community surrounding the schools done by the principala as motivators. The evaluation was based on the governemtal regulation and policies covering academic aspects, students characters, and teachers' professionalism through examination and other evaluation resultinf the better studsents' achievement, students' awareness, and enhancement of the teachers; responsibility.

To overcome problems on rthe lack of funding, lack of awareness in clean and healthy living, lack of commitment among the school community members, inexistance of the process and results measurements, inexistance of the school regulation the alternateive solution turned out to be improving the school work plan or the so-called RKAS, utilizing company CSR, improving concept of integration between character education and subject matters, enhancing school community members commitment, having the principals as tole models, maintenaning good tradition, respecting school members differences, and considering that the results of character education are used for deciding clas level promotion and graduation. The instructional leadership turned out to impact the attitude and behavior of the principals, $m$ teachers, and students in being more responsible, more discipline, more obedient in good deeds, and being noble. 
It has been suggested that principals, educsators, and educational stafs, as well as the department of education officers enhance the instructional leadership abilities in cultivating cultural norms and supporting all school community members to culturalie the noble character of the nation.

\section{References}

Kementerian Pendidikan Nasional. 2010a. Pembinaan Pendidikan Karakter di Sekolah Menengah Pertama. Jakarta: Kementerian Pendidikan Nasional.

Kementerian Pendidikan Nasional. 2010b. Pedaoman Sekolah: Pengembangan Pendidikan Budaya dan Karakter. Jakarta: Badan Penelitian dan Pengembangan Pusat Kurikulum.

Kementerian Pendidikan Nasional. 2011a. Pendidikan Karakter Bangsa: Pengembangan Pendidikan Karakter Bangsa Berkelanjutan (PPKBB). Jakarta: Direktorat Peningkatan Mutu Pendidik dan Tenaga Kependidikan, Pusat Kurikulum.

Kementerian Pendidikan Nasional. 2011b. Bahan Pelatihan: Penguatan Metodologi Pembelajaran Berdasarkan Nilai-nilai Budaya untuk Membentuk Daya Saing dan Karakter Bangsa, Pengembangan Pendidikan Karakter Bangsa. Jakarta: Direktorat Peningkatan Mutu Pendidik dan Tenaga Kependidikan, Pusat Kurikulum.

Moleong, L.J. 2006. Metodologi Penelitian Kualitatif. Edisi Revisi. Bandung: PT Remaja Rosdakarya.

Musliar, K. 2013. Urgensi Implementasi Pendidikan Karakter. (Online). (http://www.goole.com/pendidikan_karakter/), diakses tanggal 15 Januari 2014.

Peraturan Menteri Pendidikan Nasional Nomor 17 tahun 2003 tentang Karakteristik Kepemeimpinan Manajerial Kepala Sekolah. Jakarta: Kemendiknas

Peraturan Menteri Pendidikan Nasional Nomor 22 tahun 2006 tentang Standar Isi Pendidikan Dasar dan Menengah. Jakarta: Kemendiknas.

Peraturan Menteri Pendidikan Nasional Nomor 23 tahun 2006 tentang Standar Kompetensi Lulusan Sekolah Dasar dan Menengah. Jakarta: Kemendiknas.

Peraturan Menteri Pendidikan dan Kebudayaan Nomor 23 tahun 2015 tentang Penumbuhan Budi Pekerti. Jakarta: Kemendikbud.

Riyanto, 2010. Empat Model Penerapan Pendidikan Karakter di Sekolah. (Online). (http://riyantosma9yk.wordpress.com/2010/08/09/4-model-penerapan-pendidikankarakter-di-sekolah-antara-otonomi-integrasi-suplemen-dan-kolaborasi-read-more-aboutintegrasi-pendidikan-karakter-dengan-matape-lajaran-by-kang-marfu/), diakses 6 Februari 2014.

Undang-undang No. 20 tahun 2003 tentang Sistem Pendidikan Nasional. Bandung: Citra Umbara. 